Marzena Blachowska-Szmigiel

Uniwersytet im. Adama Mickiewicza w Poznaniu

blachszmi@op.pl

\title{
UCZENIE SIĘ JĘZYKÓW OBCYCH W PROCESIE SAMODOSKONALENIA I ROZWOJU KOMPETENCJI TWÓRCZYCH
}

\author{
Learning foreign languages in the process of self-improvement and \\ development of creative competences
}

The purpose of this article is to present the learning foreign languages as an activity supporting the self-improvement and the development of creative competences. The article consists of three parts. The subject of the first part is an evolution of the concept of creativity, characteristics of the research paradigms of creativity and links between the self-improvement and the creative competences. The focus of the second part is neurobiological and intrapsychic basis for self-improvement and development of creative competences. The third part shows the benefits resulting from the activity of learning foreign languages in the context of self-improvement and development of creative competences.

Keywords: learning foreign languages, self-improvement, development of creative competences

Słowa kluczowe: uczenie się języków obcych, samodoskonalenie, rozwijanie kompetencji twórczych

\section{Wprowadzenie}

Uczenie się języków obcych i biegłe posługiwanie się - najlepiej więcej niż jednym - językiem obcym to aktualny i popularny temat. Motywacji do nauki jest 
wiele. Dla części osób będą nimi: nawiązywanie nowych kontaktów, zwiedzanie świata, prestiżowa praca lub awans etc. Znajomość języków obcych jest w tym przypadku środkiem do osiągnięcia upragnionego celu, który ma zapewnić poczucie dobrostanu psychicznego. W pogoni za kolejnymi znajomościami, awansem czy wyjazdami jednostka zapomina jednak niekiedy, że to tylko zewnętrzne atrybuty szczęścia. Jego źródłem jest bowiem sama jednostka, jej dążenie do samodoskonalenia w interakcji z otoczeniem bliższym (rodzice, rodzina) i dalszym (kontekst społeczny, kulturowy) oraz z własnym Ego. Przyjęcie postawy samodoskonalenia pozwala jednostce czerpać radość z samej aktywności niezależnie od jej wyniku czy społecznej oceny. Celem staje się nabywanie kolejnych doświadczeń i wyciąganie z nich wniosków na przyszłość.

A jaką wartość zyskuje w tej perspektywie uczenie się języków obcych? W moich rozważaniach uczenie się języka obcego i jego wynik, tj. dwu- lub wielojęzyczność, ujmuję jako aktywność wspierającą samodoskonalenie i rozwijanie kompetencji twórczych. W tym celu najpierw charakteryzuję twórczość jako przedmiot badań nauk humanistycznych, następnie omawiam neurobiologiczne i psychiczne podstawy samodoskonalenia i rozwoju kompetencji twórczych, by w ostatniej części przejść do przedstawienia uczenia się języków obcych jako aktywności wpierającej samodoskonalenie i rozwijanie kompetencji twórczych.

\section{Twórczość jako przedmiot badań nauk humanistycznych}

Twórczość to złożone, wieloaspektowe zjawisko psychospołeczne, przedmiot badania i zainteresowania wielu dyscyplin naukowych. W celu przybliżenia jego złożoności w tej części rozważań przedstawiam ewolucję pojęcia twórczość i paradygmatów badawczych tego zjawiska.

\subsection{Dynamika rozumienia pojęcia twórczość}

W ciągu dwóch tysięcy lat granice reprezentacji pojęciowej twórczości otwierały się stopniowo, obejmując swym zakresem Boga, poetę, artystę, przedstawicieli świata nauki i techniki, wreszcie człowieka, a w szczególności jego styl życia, postawę, cechy i dyspozycje, aktywność wraz z jej wytworami. Obecnie w naukach humanistycznych twórczość przedstawiana jest jako zjawisko złożone i wieloaspektowe. Jego istotę stanowi aktywność ludzka, która przebiega w określonych warunkach, prowadzi do nowego, oryginalnego i wartościowego wyniku (tzn. wynalazku, odkrycia, dzieła literackiego) w wymiarze indywidualnym i/lub społecznym. Współczesne myślenie o twórczości zdominowała idea pankreacjonizmu, zgodnie z którą każde działanie człowieka wykraczające poza recepcję otaczającej rzeczywistości jest uważana za twórcze (Tatarkiewicz, 
1988: 169). Twórczość, a właściwie „kreatywność” (inaczej zachowania twórcze [Nęcka, 2001]), jest odmieniana przez wszelkie możliwe przypadki i konteksty, określana jako warunek konieczny sukcesu zawodowego, stanowi przedmiot zainteresowania współczesnych organizacji dążących do miana „organizacji uczących się” (Blachowska-Szmigiel, 2014: 6). Przekaz kultury masowej jest czytelny: w XXI wieku po prostu nie wypada nie być kreatywnym.

W konsekwencji trudno jest wyznaczyć granice między tym co twórcze, a tym co nietwórcze, jak stwierdza Popek: „Ostatnie lata przyniosły pełną demokratyzację pojęcia i zakresu twórczości (...). Twórczość może być z jednej strony czynnością intencjonalną i świadomą, z drugiej zaś może być mglistą wizją (..). Twórczość jest więc powoływaniem do istnienia wartości autonomicznych (...). Może być również autokreacją, stwarzaniem swojej istoty składającej się na niepowtarzalną osobowość człowieka" (Popek, 2003: 12). Jest zatem wiek XXI stuleciem homo creativus (Blachowska-Szmigiel, 2013). Wychodząc naprzeciw oczekiwaniom środowiska (pracodawcy), ulegając presji kultury masowej, człowiek XXI wieku buduje swój wizerunek jako jednostki kreatywnej, dążącej do rozwijania swojej wiedzy i kompetencji. Jednak w przeciwieństwie do Sokratesa, który deklarował „oida ouden eidos”, licząc na refleksję epistemologiczną i poszukiwanie prawdy, współczesne kręgi opiniotwórcze (zwłaszcza mass media) wzmacniają w człowieku nie tylko potrzebę dążenia do samorozwoju, lecz także przekonanie, że nie wypada przyznać „wiem, że nic nie wiem" lub „wiem, że tego nie wiem”. Twierdzi on zatem: „wiem, że wiem”, "wiem, że potrafię", „jestem kreatywny", wpadając w pułapkę własnego Ego, które, drżąc ze strachu przed zdemaskowaniem, podsuwa mu różne mechanizmy obronne. Homo creativus XXI wieku poczucie wiedzy i kompetencji, w tym kompetencji twórczych, czerpie najczęściej z treningów rozwoju osobistego, sesji z coachem, poradników, czasopism psychologicznych, szkoleń online. Ocena ich wartości i kompetencji trenerów czy autorów poradników nie jest przedmiotem tego artykułu, jednak powszechność i dostępność wszelkiego rodzaju szkoleń, treningów czy sesji (pseudo?)coachingowych online może budzić wątpliwości, skłaniać do refleksji i pytań, także natury deontologicznej.

Kreatywność, jako istotny komponent treningów rozwoju osobistego, jeden z kluczowych celów coachingu, wreszcie modny temat poradników, wpisuje się w ścieżkę samodoskonalenia jednostki, wywołując w niej i wzmacniając potrzebę rozwoju. Współczesne stulecie na twórczość patrzy z perspektywy humanistycznej, wartością są obecnie nie tyle pojedyncze zachowania twórcze (tj. zachowania wyróżniające się nowością, oryginalnością i wartością), co postawa twórcza, inaczej mówiąc - nadrzędna struktura osobowości obejmująca wymiar charakterologiczny (zachowania nonkonformistyczne) i poznawczy (zachowania heurystyczne) (Popek, 2004). Postawa twórcza jest zatem trwałą tendencją w 
zachowaniach podmiotu, wyrażającą się między innymi jego otwartością na nowe doświadczenia, umiejętnością adaptacji do otoczenia, dążeniem do samorozwoju, giętkością, płynnością, oryginalnością i elaboracją myślenia.

\subsection{Paradygmaty badań twórczości}

Począwszy od drugiej połowy XX wieku w badaniach twórczości ustalają się cztery podstawowe paradygmaty: produktu, ekologiczny, procesu i osoby. Pierwszy odnosi się do właściwości rezultatu aktywności twórczej, drugi do cech środowiska twórczego, kolejny ukierunkowuje refleksję na właściwości myślenia twórczego oraz właściwości i przebieg procesu twórczego. Ostatni paradygmat dotyczy twórczych cech i dyspozycji osobowych oraz cech i dyspozycji twórców reprezentujących tzw. twórczość wysoką, określaną także jako „twórczość przez T” (Nęcka, 2001: 20) czy „twórczość historyczna” (Kozielecki, 2000: 186), a więc taką, która prowadzi do stworzenia dzieła społecznie uznanego za nowe, oryginalne i wartościowe. Badania twórczości obejmują z jednej strony wewnątrzosobowe i środowiskowe uwarunkowania tego zjawiska z drugiej - psychospołeczne kategorie aktywności twórczej, tj. przejawy twórczości obserwowane w różnych sferach działalności jednostki.

Kryteria wyodrębniania psychospołecznych kategorii aktywności twórczej odnoszą się do wymienionych wcześniej paradygmatów, a składają się na nie: obszar (nauka, sztuka, technika), środowisko, motywy podjęcia działań twórczych, środki ekspresji i komunikacji (niewerbalne, figuralne, język naturalny, figuralno-symboliczny), rezultat (odkrycie, wynalazek, dzieło, produkt działalności publicznej) oraz perspektywa oceny wyniku aktywności twórczej (indywidualnej i/lub społecznej). Z badań przejawów aktywności twórczej w różnych sferach działalności jednostki wyłania się między innymi:

- $\quad$ psychologiczny portret twórczego ucznia, nauczyciela, menedżera itd.;

- charakterystyka cech twórczych zadań, tzn. takich, które stymulują rozwój dyspozycji twórczych i/lub wymagają ich użycia;

- charakterystyka cech twórczego środowiska, tzn. środowiska stymulującego wzrost dyspozycji twórczych (w kontekście nauki o organizacjach mówi się np. o „klimacie twórczym organizacji”);

- cech twórczego produktu i kryteriów oceny produktu twórczego.

Badania osobowościowych uwarunkowań zachowań twórczych prowadzą do wyłonienia struktur cech twórczych i odtwórczych (Popek, 2004) oraz do rozróżnienia cech osobowości twórcy i cech osobowości twórczej. Charakteryzując osobowość twórcy i osobowość twórczą, w rozmowie z Karaś i Knopikiem (2005: 9), Sękowski podkreśla, że w pierwszym przypadku chodzi o „cechy ludzi, którzy wyróżniają się szczególnymi osiągnięciami na polu szeroko rozumianej 
kultury (...), nauk ścisłych czy medycznych". Wśród cech twórców badacz wymienia brak stabilności emocjonalnej, nonkonformizm, kierowanie się wewnętrznymi standardami, własnym systemem wartości, różnorodność i oryginalność zainteresowań, wybitną inteligencję i pracowitość. Twórcy, co zaznacza Sękowski, bywają wyalienowani i samotni. W przypadku zaś osobowości twórczej chodzi o cechy sprzyjające podejmowaniu aktywności twórczej występujące u wszystkich ludzi, ale na różnym poziomie, np. wysokie poczucie wartości Ja, samokrytycyzm, otwartość, elastyczność adapta cyjną (Karaś, Knopika, 2005: 9). W koncepcji postawy twórczej Popka (2004) wymienione cechy składają się na charakterologiczny wymiar zachowań twórczych, który autor określa jako „postawę nonkonformistyczną”. Cechy te, uwarunkowane genetycznie, kształtują się w ontogenezie pod wpływem środowiska, a ich rozwój można stymulować podczas treningów kreatywności.

Dynamicznie rozwijające się nauki poznawcze, zwłaszcza neurobiologia i psychologia poznawcza, pozwalają na coraz pełniejsze zrozumienie neurologicznych uwarunkowań zachowań twórczych oraz zrozumienie natury i swoistości twórczych procesów poznawczych, w tym myślenia twórczego. Na poziomie poznawczym kluczowym uwarunkowaniem zachowań twórczych jest myślenie synwergentne, inaczej mówiąc myślenie, które cechuje dynamiczna równowaga między przetwarzaniem konwergencyjnym (tj. zbieżnym, sekwencyjnym, logicznym) a dywergencyjnym (tj. rozbieżnym, którego istotą jest wymyślanie różnych pomysłów w odpowiedzi na problem otwarty). Równowaga ta przejawia się zdolnością jednostki do generowania wielu zróżnicowanych pomysłów oraz zdolnością dokonywania wyboru tego spośród nich, który zostanie zrealizowany (Blachowska-Szmigiel, 2011).

Na poziomie neurologicznym twórczość uwarunkowana jest neuroplastycznością mózgu, tzn. zdolnością układu nerwowego do adaptacji, zmienności, samonaprawy, uczenia się i pamięci (Kossut, 2016: 260). Wbrew dogmatowi o stałości połączeń nerwowych w dorosłym mózgu (sformułowanemu pod koniec XIX wieku przez Santiago Ramona y Cajala), szlaki neuronalne reorganizują się w ciągu całego życia człowieka (tamże: 285-306). Badania prowadzone w dziedzinie neurobiologii wykazują, że przebieg tego procesu zależy od rodzaju i intensywności napływających bodźców (Piesiak, 2013: 57). Stymulowanie dyspozycji i cech twórczych jednostki przez treningi kreatywności wpływa zatem na wzorzec połączeń pomiędzy ośrodkami w układzie nerwowym, utrzymując mózg w dobrej kondycji. Z drugiej zaś strony, dostarczając mózgowi wciąż nowych bodźców (tj. wykraczając poza rutynowe czynności), stwarzamy korzystne warunki dla wzrostu i rozwoju naszych cech i dyspozycji twórczych.

Podsumowując, rozwój kompetencji twórczych wpisuje się w kontekst samodoskonalenia, a więc intencjonalnego dążenia jednostki do rozwoju wiedzy, 
kompetencji, kształcenia nowych zachowań czy pozbywania się niechcianych nawyków. U podstaw zaś samodoskonalenia leży świadome stymulowanie aktywności szlaków neuronalnych mózgu przez dostarczanie mu nowych bodźców w ciągu całego życia. Inaczej mówiąc, oznacza to wychodzenie poza rutynowe czynności, nabywanie nowych umiejętności. Do takich działań należy bezsprzecznie aktywność uczenia się kolejnego języka obcego i posługiwania się nim. Działając w taki sposób, jednostka tworzy sprzyjające warunki dla podejmowania zadań i aktywności zorientowanych intencjonalnie na wzrost oraz rozwój cech i dyspozycji twórczych.

\section{Neurobiologiczne i wewnątrzpsychiczne podstawy samodoskonalenia i rozwoju kompetencji twórczych}

Dynamika procesu samodoskonalenia i rozwijania kompetencji twórczych jest uwarunkowana czynnikami biologicznymi, wewnątrzpsychicznymi i środowiskowymi. Złożoność tych uwarunkowań oddają koncepcje samodoskonalenia (np. coaching, empowerment) oraz koncepcje i modele twórczości rozwijające się w ramach podejścia typologicznego i interakcyjno-relacyjnego (Blachowska-Szmigiel, 2010: 71). Abstrahując od podejść, koncepcji czy modeli, samodoskonalenie i wpisujące się w jego kontekst rozwijanie kompetencji twórczych sprowadza się do świadomego stymulowania aktywności szlaków neuronalnych mózgu. Kluczowy zaś wpływ na przebieg, tempo, rytm i rezultat tego procesu ma Ego jednostki, tj. ta część świadomości, która odpowiada za myśli podmiotu, jego wybory i decyzje, równoważy struktury osobowości (tzn. struktury Superego i Ego idealnego wbrew instynktom i popędom Id) oraz zestraja osobowość z rzeczywistością zewnętrznego świata (Hawkins, 2012: 168).

\subsection{Stymulowanie aktywności szlaków neuronalnych mózgu jako podstawa samodoskonalenia i rozwoju kompetencji twórczych}

Z perspektywy neurobiologicznej samodoskonalenie jest warunkiem koniecznym dla utrzymania mózgu, a w konsekwencji także umysłu, w dobrej kondycji w ciągu całego życia. W ontogenezie prawidłowa stymulacja mózgu (tj. odpowiednia dawka i jakość bodźców w zależności od okresu sensytywnego) konieczna jest dla harmonijnego rozwoju i wzrostu funkcji motorycznych i psychicznych jednostki. Natomiast w przypadku dorosłego mózgu nie wykazującego zmian neuropatologicznych dostarczanie nowych bodźców istotne jest dla jego prawidłowego funkcjonowania poznawczego i optymalnego starzenia 
się (Piesiak, 2013: 56-66). Świadome podejmowanie aktywności wykraczających poza rutynowe działania można zatem rozumieć jako wyraz troski jednostki o jakość swojego życia psychicznego i duchowego.

Ilustracją powyższej tezy jest koncepcja „supermózgu” Czopry i Tanziego (2014). Jej autorzy istotę postawy twórczej sprowadzają do twórczego podejścia do własnego mózgu, które charakteryzują odwołując się do koncepcji poczwórnej roli pełnionej wobec niego: przywódcy, wynalazcy, nauczyciela i użytkownika. Każda z wymienionych ról ilustruje inny aspekt postawy twórczej. Rolę przywódcy cechuje niechęć do powtarzalności i rutyny przy jednoczesnej otwartości na nowość i gotowości na zmiany. Wynalazcę wyróżnia chęć rozwijania się przez całe życie, łatwość adaptacji do zmian oraz podejmowania nowych wyzwań i aktywności. Rola użytkownika wyraża się między innymi w poczuciu kontroli nad własnym życiem oraz $w$ aktywnym podejściu do sytuacji stresujących. Pełniąc wobec własnego mózgu rolę nauczyciela, jednostka czuje chęć wymyślania siebie na nowo, czerpie natchnienie z życia codziennego, jest ekspertem przynajmniej w jednej dziedzinie, wyróżnia się umiejętnością zmiany utrwalonego poglądu albo przekonania i dobrym nastrojem.

\subsection{Ambiwalentna dynamika Ego $w$ procesie samodoskonalenia i rozwoju kompetencji twórczych}

W perspektywie psychologicznej samodoskonalenie i wpisujący się w jego kontekst rozwój kompetencji twórczych są wzmacniane przez postawę twórczą. Podstawową zaś przeszkodą na tej drodze jest Ego jednostki. Sprawując kontrolę nad przeżywanymi uczuciami, Ego chroni jednostkę przed destrukcyjnymi konsekwencjami negatywnych emocji (lęku, wstydu, poczucia winy, rozpaczy czy agresji), wypartymi pragnieniami i myślami, redukując $w$ ten sposób poziom stresu odczuwanego. Niepowodzenie zaś tej operacji prowadzi do nagłego wzrostu tłumionej wściekłości, strachu i depresji oraz do pojawienia się cech i stanów patologicznych (Hawkins, 2012: 168). W celu ochrony spójności osobowości, Ego aktywuje mechanizmy obronne, których motywy pozostają nieświadome, oraz w pełni świadome strategie adaptacyjne. W odróżnieniu od strategii adaptacyjnych, które mają charakter funkcjonalny, mechanizmy obronne mogą być zarówno funkcjonalne, jak i dysfunkcjonalne, co więcej, zniekształcają zachowania lub ogląd rzeczywistości. To ich aktywowanie może spowalniać, a nawet blokować proces samodoskonalenia i rozwoju kompetencji twórczych.

O dysfunkcjonalnym mechanizmie obronnym mówimy wówczas, gdy jego wybór i sposób aktywacji nie są dostosowane do poziomu stresu odczuwanego oraz w sytuacji stresu długotrwałego. $W$ tym drugim przypadku w wyniku nadmiernego stosowania mechanizmów obronnych jednostka przestaje być 
zdolna do realnej oceny siebie i swojego działania. O funkcjonalnym mechanizmie obronnym mówimy wówczas, gdy jego wybór i sposób aktywacji są dostosowane do poziomu stresu odczuwanego. Optymalną adaptację do niskiego natężenia stresu odczuwanego zapewniają dojrzałe mechanizmy obronne, takie jak: antycypacja, afiliacja, afirmacja siebie, altruizm, samoobserwacja, humor, sublimacja czy tłumienie (Chabrol, 2005: 31-42). W przypadku tych mechanizmów percepcja uczuć i myśli wraz z ich konsekwencjami jest świadoma. Działanie dojrzałych mechanizmów obronnych jest zatem bliskie strategiom adaptacyjnym, mechanizmy te najmniej zniekształcają zachowania lub ogląd rzeczywistości. Jednak im silniejsze są uczucia destrukcyjne, im trudniejsze wyparte myśli i pragnienia, tym wyższe natężenie stresu odczuwanego w konfrontacji z rzeczywistością świata zewnętrznego, w konsekwencji tym więcej energii psychicznej Ego wydatkuje na obronę, a sposób aktywacji mechanizmu i jego rodzaj dostosowuje do okoliczności. Tym samym w przypadku wysokiego natężenia stresu odczuwanego funkcję adaptacyjną pełnią mechanizmy określane jako niedojrzałe czy patologiczne (np. idealizacja, zaprzeczenie, projekcja czy racjonalizacja) (tamże).

Z perspektywy procesów samodoskonalenia i rozwijania kompetencji twórczych kluczowe znaczenie ma siła negatywnych uczuć: lęku, wstydu, poczucia winy, rozpaczy, agresji oraz wyparte treści myśli i pragnień. To od niej bowiem zależy wybór mechanizmów obronnych, które w konsekwencji wpływają na dynamikę omawianych procesów. Im większa siła uczuć destrukcyjnych, im trudniejsze treści wypartych myśli i pragnień, tym bardziej dynamika procesów samodoskonalenia i rozwijania kompetencji twórczych jest zaburzona przez działania Ego skupiające się na cenzurze, np. obronie przed uczuciem wstydu na myśl o zabraniu głosu na lekcji języka obcego. W sytuacji ekstremalnej każde działanie wykraczające poza rutynowe czynności Ego interpretuje jako zagrożenie dla integralności osobowości i aktywuje mechanizmy obronne. W tych okolicznościach zasoby energii psychicznej, które mogłyby zasilić proces samodoskonalenia, są zwyczajnie marnotrawione. Dla prawidłowego przebiegu procesów samodoskonalenia i rozwoju kompetencji twórczych istotne jest więc dążenie do optymalizacji zużycia zasobów energii psychicznej, inaczej mówiąc, dążenie do stanu zdrowia psychicznego określanego także jako dobrostan psychiczny, emocjonalny, poznawczy czy trwałe uczucie szczęścia (Buffet, 2012: 21).

Do osiągnięcia dobrostanu prowadzą różne drogi, w zależności od rodzaju i stopnia zaburzenia psychicznego, samoświadomości i gotowości do podjęcia trudu pracy nad sobą. W kulturze zachodu z jednej strony leczy się zaburzenia, czym zajmują się nauki medyczne (tj. psychopatologia, psychologia 
kliniczna, psychiatria) i psychologia (tj. psychoterapia, proponowana w ramach różnych podejść psychologicznych, oraz podejścia eklektyczne), z drugiej promuje się rozwój dyspozycji i kompetencji jednostki przez treningi rozwoju osobistego, warsztaty czy coaching. Coraz większą popularnością cieszy się koncepcja empowerment, która wyrosła z rozczarowania psychologią kliniczną, na gruncie psychologii humanistycznej i pozytywnej. Koncepcja ta umiejętnie łączy zagadnienie uświadamiania sobie zaburzeń i zdrowienia z kwestią rozwijania wiedzy i kompetencji. Empowerment opiera się bowiem na założeniu, że człowiek jest aktorem własnego życia i może sprawować nad nim kontrolę dzięki zaangażowaniu w pracę nad sobą, rozwijaniu własnych kompetencji, poczuciu własnej wartości i świadomości krytycznej, która przejawia się w umiejętności podważania swojego status quo (tamże: 26). Przykładem podejścia opierającego się na koncepcji empowerment jest MA-URI wywodzące się z Nowej Zelandii. O ile w psychoterapii zasadniczym medium w relacji terapeuta-pacjent jest język, a sesja terapeutyczna polega na rozmowie, o tyle w MA-URI rolę medium w kontakcie praktyk-klient pełni świadomy dotyk, a sesja „body work” polega na tanecznym masażu. Jej zasadniczym celem nie jest redukcja napięć na poziomie fizjologicznym, lecz uwolnienie traumatycznych wspomnień czy trudnych, negatywnych uczuć, a w konsekwencji doprowadzenie do uzdrowienia (Rychlewska-Suska, 2014).

\section{Uczenie się języków obcych jako aktywność wspierająca samodoskonalenie i rozwój kompetencji twórczych}

Jak już wcześniej zostało powiedziane, świadome podejmowanie aktywności wykraczających poza rutynowe działania jest warunkiem koniecznym dla utrzymania mózgu i umysłu w dobrej kondycji w ciągu całego życia. Co więcej, stwarza ono sprzyjające warunki dla intencjonalnego rozwijania kompetencji twórczych. Tempo, rytm, przebieg i wynik aktywności wyznacza Ego, które w swym dążeniu do zachowania integralności osobowości może spowalniać, a nawet blokować podejmowanie przez jednostkę nowych działań. W tej perspektywie aktywność uczenia się języka obcego (pierwszego i kolejnych) oraz posługiwanie się nim (nimi), czyli dwu- i wielojęzyczność, staje się wartością samą w sobie, wpisując się w ścieżkę samodoskonalenia jako jedno z narzędzi stymulujących rozwój jednostki (w tym rozwój jej kompetencji twórczych). Wartością jest zatem samo podjęcie czynności uczenia się języka obcego oraz wykonywanie jej z pełnym zaangażowaniem i w skupieniu, jak również posługiwanie się językiem obcym. Ocena i certyfikacja wiedzy językowej przestaje być wyznacznikiem sukcesu (porażki) w uczeniu się języka obcego, staje się cenną informacją zwrotną, przyczynkiem do refleksji. Świadome dążenie do 
samodoskonalenia skłania do myślenia o czynności uczenia się języków obcych i posługiwaniu się nimi (dwu- i wielojęzyczności) w kategoriach treningu korzystnie wpływającego na nasz mózg i umysł.

Ten korzystny wpływ potwierdzają badania neurologiczne, psychologiczne i psycholingwistyczne.

\subsection{Badania neurologiczne}

Jak wykazują badania Bialystok (za Bertelle, 2011: 240-249), uczenie się języka obcego (języków obcych), a w konsekwencji także posługiwanie się językiem obcym (językami obcymi), korzystnie wpływa na aktywność bioelektryczną mózgu, aktywność półkul mózgowych i sprawność kory przedczołowej, tworzy także rezerwy kognitywne w mózgu:

- aktywność bioelektryczna mózgu zmienia się w zależności od czynności, którą wykonujemy. Zbyt długie przebywanie na jednej częstotliwości ma niekorzystny wpływ na nasze zdrowie: prowadzi do zaburzeń koncentracji, stanów depresyjnych, przedwczesnego starzenia się. Badania wykazują, że aktywność bioelektryczna mózgu zmienia się już na początku nauki języka obcego;

- przetwarzanie danych jednocześnie w języku ojczystym i docelowym zwiększa aktywność obu półkul mózgowych;

- $\quad$ ucząc się nowego języka, ćwiczymy korę przedczołową odpowiadającą za funkcjonowanie pamięci roboczej, planowanie ruchów i działań oraz rozważanie ich konsekwencji, przełączanie funkcji wykonawczej, kontrolę spontanicznych, gwałtownych emocji, których źródłem jest podwzgórze i układ limbiczny;

- dwujęzyczność sprzyja tworzeniu kognitywnych rezerw w mózgu, a w konsekwencji działa ochronnie na demencję i rozwój choroby Alzheimera, tzn. może opóźniać pewne objawy tej choroby, a mianowicie kłopoty z pamięcią, dezorientację czy trudności z rozwiązywaniem problemów i planowaniem.

\subsection{Badania kompetencji poznawczych i komunikacyjnych}

W zakresie wpływu uczenia się języka obcego na kompetencje poznawcze i komunikacyjne oraz posługiwania się nim badania wykazują, że dwujęzyczność:

- zwiększa giętkość umysłową, która jest istotną cechą myślenia twórczego. „Przełączając” się między nazwami tych samych obiektów, jednostka „przełącza się” jednocześnie między punktami widzenia (Bialystok za Bertelle, 2011: 243); 
- zwiększa łatwość wykonywania wielu zadań, ponieważ dzięki umiejętności poruszania się wśród dwóch systemów językowych osoby dwujęzyczne szybciej przełączają się z jednej czynności na drugą (tamże);

- ma pozytywny wpływ na zarządzanie zasobami uwagi, co przekłada się na większą umiejętność skupienia się na zadaniach pomimo celowego rozpraszania uwagi (tamże: 240-249);

- ma korzystny wpływ na rozwój myślenia i rozwiązywania problemów osoby dwujęzyczne szybciej osiągają etap abstrakcyjnego myślenia, sprawniej analizują złożone informacje, dokonując trafnej selekcji informacji ważnych, mają większą łatwość myślenia dywergencyjnego (Étude sur la contribution du multilinguisme à la créativité. Rapport final, 2009: 5-10);

- korzystnie wpływa na zapamiętywanie i uczenie się, a mianowicie: pamięć epizodyczną i semantyczną, zdolności zapamiętywania, organizowania i przypominania sobie, uporządkowanie myśli i ich złożoność składniową (tamże);

- korzystnie wpływa na rozwój kompetencji komunikacyjnej - osoby dwujęzyczne mają większą umiejętność odczytywania intencji i celu komunikatów, większą wrażliwość na implicytny i parawerbalny poziom komunikatu, większą łatwość wykrywania różnicy zdań i błędnych twierdzeń (tamże).

Podsumowując, niezależnie od kosztów poznawczych czy zjawiska interferencji, które towarzyszą uczeniu się języka obcego (pierwszego czy kolejnego), należy ono do aktywności wpierającej prawidłowe funkcjonowanie naszego mózgu.

\section{Podsumowanie}

Uczenie się języka/języków obcych i posługiwanie się nim/nimi rozpatrywane w perspektywie samodoskonalenia i rozwijania kompetencji twórczych zyskuje nowy wymiar, staje się jednym z narzędzi, którymi jednostka może się posłużyć, by świadomie zadbać o kondycję własnego mózgu/umysłu, a w konsekwencji o swoje zdrowie psychiczne i rozwój kompetencji twórczych, między innymi rozwój giętkości myślenia i myślenia dywergencyjnego. Optymalne wykorzystanie tego narzędzia uwarunkowane jest dynamiką Ego, które w celu kontroli negatywnych uczuć („Nie, ja w tym wieku to już języka obcego się nie nauczę. Sami młodzi na kurs przychodzą!") aktywuje mechanizmy obronne hamujące czy też blokujące potencjał jednostki. 


\section{BIBLIOGRAFIA}

Bertelle, L. 2011. „Dwujęzyczność w świetle najnowszych badań”. Lingwistyka stosowana, 4: 241-249.

Blachowska-Szmigiel, M. 2010. Twórcze schematy poznawcze a kreatywność językowa. Na przykładzie języka francuskiego jako obcego. Poznań: Wydawnictwo Naukowe UAM.

Blachowska-Szmigiel, M. 2011. „Développer la pensée convergente et divergente en cours de FLE". (w) Études françaises dans la société du XXI siècle. Défis et perspectives. (red. E. Biardzka). Seria Prace naukowe Akademickiego Towarzystwa Romanistów Polskich „Plejada”. Łask: Oficyna Wydawnicza LEKSEM, str. 13-24.

Blachowska-Szmigiel, M. 2013. „Zadania zorientowane na ekspresję teatralną jako narzędzie wspierające rozwój kreatywności językowej studenta filologii romańskiej". Neofilolog, 40/1: 29-41.

Blachowska-Szmigiel, M. 2014. „Le coaching trouvera-t-il sa place dans le développement des compétences créatives des enseignants du FLE en Pologne?" (w) Les innovations en des langues étrangères. (red. M. Blachowska-Szmigiel). Studia Romanica Posnaniensia XLI/3. Poznań: Wydawnictwo Naukowe UAM, str. 3-15.

Buffet, I.W. 2012. Acteur de sa vie. Développer l'empowerment. Mieux être au travail et dans sa vie personnelle. Paris: Mon Petit Editeur.

Chabrol, H. 2005. „Les mécanismes de défense”. Recherche en soins infirmiers, 2005/3 (82), 31-42.

Czopra D. i R.E. Tanzie. 2014. Twój supermózg. Warszawa: Wydawnictwo Ole.

Marsh, D. i R. Hill (red.) 2009. Étude sur la contribution du multilinguisme à la créativité. Rapport final. Bruxelles: Europublic sca/cva.

Hawkins, D.R. 2012. Przekraczanie poziomów świadomości. Schody do oświecenia. Warszawa: Wydawnictwo Virgo.

Karaś, A. i T. Knopika. 2005. „Postawa twórcza - źródło szczęścia czy kula u nogi? Rozmowa Agnieszki Karaś i Tomasza Knopika z prof. Andrzejem Sękowskim”. Zeszyty Szkolne 2005/1 (15): 8-13.

Kossut M. „Synapsy i plastyczność mózgu”. (w) Nauka światowa i polska, www.funda cjarozwojunauki.pl 285-306 DW 10.01.2016, str. 285-305.

Kozielecki, J. 2000. Koncepcje psychologiczne człowieka. Warszawa: Wydawnictwo Naukowe Żak. Nęcka, E. 2001. Psychologia twórczości. Gdańsk: GWP.

Piesiak, W. 2013. „Genetyka i starzenie się mózgu”. (w) Sympozja II: Neurokognitywistyka w patologii i zdrowiu 2011-2013. Szczecin: Wydawnictwo Annales Academiae Medicae Stetinesis, str. 56-66.

Popek, S. 2003. Człowiek jako jednostka twórcza. Lublin: UMCS.

Popek, S. 2004. Kwestionariusz Twórczego Zachowania KANH. Lublin: UMCS.

Rychlewska-Suska, J. 2014. MA-URI dar życia i moc kreacji. Wewnętrzna podróż ku świadomemu poczęciu i życiu w wolności.

Tatarkiewicz, W. 1988. Dzieje sześciu pojęć. Warszawa. PWN. 